\title{
Enhanced Cd(II) Uptake by the Bassanite Phase Contained in Waste Calcite Produced via the Carbonation of Flue Gas Desulfurization (FGD) Gypsum
}

\author{
Kyungsun Song, Young-Nam Jang, Jun-Hwan Bang, Soo-Chun Chae and Wonbaek Kim* \\ Korea Institute of Geoscience \& Mineral Resources (KIGAM), Gwahang-no 92, Yuseong-gu, Daejeon, 305-350, Korea
}

The uptake of Cd(II) by waste calcite, a by-product of the carbonation of flue gas desulfurization (FGD) gypsum, was investigated in a batch experiment. The uptake of $\mathrm{Cd}$ (II) by and the dissolution of $\mathrm{Ca}$ (II) from the waste calcite particles were monitored simultaneously as a function of exposure time to $0.89 \mathrm{mM} \mathrm{Cd}(\mathrm{II})$ solution. The reagent-grade calcite particles were also examined for a comparative study. The waste calcite contained bassanite, dolomite, and muscovite as the major impurity phases. X-ray diffraction study revealed that the bassanite phase dissolved almost completely during the 1st hour of the exposure to the solution while other phases were intact for two days. The amount of removed $\mathrm{Cd}(\mathrm{II})$ was found to be proportionally related to dissolved $\mathrm{Ca}$ (II) reflecting the exchange nature of the adsorption. The use of waste calcite instead of reagent-grade calcite enhanced $\mathrm{Ca}$ (II) dissolution and thereby $\mathrm{Cd}$ (II) uptake significantly. The waste calcite removed about $90 \%$ of initial Cd(II) while reagent calcite removed only $6 \%$ during the exposure for 2 days to $0.89 \mathrm{mM}$ Cd(II) solution. The enhanced Ca(II) dissolution and $\mathrm{Cd}(\mathrm{II})$ uptake by the waste calcite were attributed to the fast-dissolving bassanite phase which provides the substantial quantity of $\mathrm{Ca}$ (II) and sulfate ions to the calcite/solution interface. [doi:10.2320/matertrans.M2011031]

(Received January 24, 2011; Accepted March 10, 2011; Published May 18, 2011)

Keywords: cadmium, calcium carbonate, sorption, bassanite

\section{Introduction}

Calcite is an environmentally ubiquitous adsorbent for divalent metals, and sorption studies have been performed for natural as well as treatment systems. ${ }^{1-5)}$ Among the divalent metals, cadmium (Cd) has attracted the most scientific and practical interest because it is known to have a similar ionic radius to that of $\mathrm{Ca}$ (about $98 \%$ of that of $\mathrm{Ca}$ ) and a high sorption affinity to calcite. ${ }^{4,5)}$

Generally accepted mechanisms involved in calcium dissolution and cadmium adsorption on calcite are explained in terms of the following equations. ${ }^{1,5,6)}$ The dissolution of calcium from calcium carbonate with atmospheric $\mathrm{CO}_{2}$ gas is established as follows:

$$
\mathrm{CaCO}_{3}(\mathrm{~s})+\mathrm{CO}_{2}(\mathrm{~g})+\mathrm{H}_{2} \mathrm{O}=\mathrm{Ca}^{2+}+2 \mathrm{HCO}_{3}{ }^{-}
$$

Meanwhile, cadmium adsorption on calcite is interpreted as an adsorption at the surface via ion exchange of $\mathrm{Cd}$ ions in solution with $\mathrm{Ca}$ in solid calcite crystal as follows:

$$
\mathrm{Cd}^{2+}+\mathrm{CaCO}_{3}(\mathrm{~s})=\mathrm{CdCO}_{3}(\mathrm{~s})+\mathrm{Ca}^{2+}
$$

Previous studies on the uptake of cadmium by calcite could be largely divided into two categories from its point of view: understanding of $\mathrm{Cd}$ (II) chemistry in a geochemical cycle or application of $\mathrm{Cd}$ (II) removal to waste water treatment. In the geochemical sector, specifically refined experimental conditions were employed. For example, solutions pre-equilibrated with calcite and of low $\mathrm{Cd}(\mathrm{II})$ concentration were used to minimize the calcium dissolution and to prevent the formation of otavite $\left(\mathrm{CdCO}_{3}\right)$ during sorption processes. $\left.{ }^{1,6}\right)$ Calcite single crystal cleavage surface was often utilized in microscopic studies ${ }^{5,7)}$ to better define the surface chemistry and structure of the sorption products. In addition, the effects of reaction parameters (i.g., temperature, ionic strength, $\mathrm{pH}$, particle size, dissolved species, etc.) on $\mathrm{Cd}(\mathrm{II})$ uptake by calcite have extensively studied. ${ }^{4,8-11)}$ On the other hand, at

*Corresponding author, E-mail: wbkim@kigam.re.kr conditions of conventional water treatment, the uptake of Cd(II) always occurs with the concurrent dissolution of calcite. However, in this case, an emphasis was usually put on the extent of $\mathrm{Cd}(\mathrm{II})$ removed. ${ }^{2,3,8)}$

Gypsum has been produced as a byproduct in flue gas desulfurization (FGD) systems which are applied to control $\mathrm{SO}_{\mathrm{x}}$ gas at coal-fired power plants. It is known as FGD gypsum and landfilled as waste though its potential use for the synthesis of ammonium sulfate (a fertilizer) has been documented. $^{12,13)}$

$$
\begin{aligned}
& \mathrm{CaSO}_{4} \cdot 2 \mathrm{H}_{2} \mathrm{O}+\mathrm{CO}_{2}+2 \mathrm{NH}_{3} \\
& \quad \rightarrow \mathrm{CaCO}_{3}+\left(\mathrm{HN}_{4}\right)_{2} \mathrm{SO}_{4}+\mathrm{H}_{2} \mathrm{O}
\end{aligned}
$$

Calcium carbonate particles can be separated by filtering since the ammonium sulfate exists in dissolved form in aqueous solution as in eq. (1). This waste calcite is known to carry impurities which are retained in FGD gypsum. ${ }^{13)}$ It contains impurities as minor carbonate minerals or trace metals which may affect the uptake of $\mathrm{Cd}(\mathrm{II})$ to a certain degree. We previously reported the uptake of $\mathrm{Cd}(\mathrm{II})$ on the waste calcite giving an attention to a maximum amount and overall kinetic aspect of the uptake. ${ }^{14)}$ However, we failed to give a specific attention to the effect of minor impurity phases contained in the waste calcite.

The objective of this study was to evaluate the role of major impurity phases contained in the waste calcite on $\mathrm{Cd}(\mathrm{II})$ uptake. The extent of removed $\mathrm{Cd}(\mathrm{II})$ from and released $\mathrm{Ca}$ (II) to the solution was monitored simultaneously. A reagent grade $\mathrm{CaCO}_{3}$ was also examined for comparison. A relatively high initial concentration $(100 \mathrm{mg} / \mathrm{L}, 0.89 \mathrm{mM})$ was selected for $\mathrm{Cd}(\mathrm{II})$ solution since it is the common value in engineering sorption studies. ${ }^{15,16)}$

\section{Experimental Procedure}

\subsection{Materials}

$\mathrm{Cd}(\mathrm{II})$ stock solution $(1,000 \mathrm{mg} / \mathrm{L})$ was prepared by dissolving $\mathrm{CdCl}_{2}$ (Sigma-Aldrich, ACS grade). Ionic strength 
of all solutions was maintained using $\mathrm{NaCl}$ (Sigma-Aldrich, ACS grade) and deionized water purified with a Milli-Q $18 \mathrm{M} \Omega-\mathrm{cm}$ system was used. The cadmium sorption for comparison was conducted with reagent-grade $\mathrm{CaCO}_{3}$ (Junsei Co.). The adsorbent was prepared from the reaction of FGD gypsum (Yeongheung Thermal Power Plants, Incheon, Korea) with $\mathrm{CO}_{2}$ gas. The specific surface areas of adsorbents were determined by the BET method of $\mathrm{N}_{2}$ gas adsorption (ASAP 2010, Micromeritics). The polymorph of the obtained adsorbent and impurity phases were determined using X-ray diffraction (XRD; X'pert MPD, Philips). Scanning electron images of adsorbents were obtained using a field emission scanning electron microscope (FE-SEM; S4700, HITACHI).

\subsection{Macroscopic experiments}

Batch experiments were performed in duplicate using $100 \mathrm{mg} / \mathrm{L}$ of $\mathrm{Cd}(\mathrm{II})(500 \mathrm{~mL})$ solution and $10 \mathrm{~g} / \mathrm{L}$ of the adsorbent for $48 \mathrm{~h}$ at a temperature of $25 \pm 1^{\circ} \mathrm{C}$. Constant ionic strength was maintained using $10 \mathrm{mM} \mathrm{NaCl}$. pH was not controlled but the $\mathrm{pH}$ variation during the experiment was insignificant. It was maintained at $7.2 \pm 0.3$ between initial and equilibrium time for waste calcite. Especially, for a reagent calcite, $\mathrm{pH}$ was rarely varied and stayed at 7.0 \pm 0.1 . For the comparison purpose, a reagent-grade $\mathrm{CaCO}_{3}$ was also tested under identical conditions. The $\mathrm{Cd}(\mathrm{II})$ solution was analyzed using ICP-OES (Optima 5300dV, Perkin-Elmer) after filtering through a $0.2 \mu \mathrm{m}$ membrane filter (cellulose acetate, Sartorius) and acidifying with instrumental grade $\mathrm{HNO}_{3}$. Other metal cations except $\mathrm{Cd}$ were not detected in a filtrate during sorption reactions. The analytical detection limit for $\mathrm{Ca}$ and $\mathrm{Cd}$ was $0.02 \mathrm{mg} / \mathrm{L}$ and uncertainty was less than $10 \%$ with replicates.

\section{Results and Discussion}

\subsection{Characterization of waste calcite}

Figure 1 shows the X-ray diffraction patterns of the reagent-grade calcite and waste calcite. The reagent-grade calcite peaks match the standard pattern (JCPDS 47-1743) and do not show any detectable amount of impurity phases. The existence of these minerals could be confirmed by the standard XRD patterns (JCPDS). Since their peaks are very small they should match the largest peak of the standard patterns to be positively identified. The waste calcite consisted of $\mathrm{CaCO}_{3}$ with second phases as bassanite (JCPDS 45-848), dolomite (JCPDS 36-426), and muscovite (JCPDS 7-25) as marked on the XRD pattern of Fig. 1(b). Here, (a) is the pattern of reagent-grade calcite, (b) is the pattern of waste calcite. On the Fig. 1, B represents bassanite $\left(\mathrm{CaSO}_{4}\right.$. $\left.0.5 \mathrm{H}_{2} \mathrm{O}\right)$, D represents dolomite $\left(\mathrm{CaMg}\left(\mathrm{CO}_{3}\right)_{2}\right)$, M represents muscovite $\left(\mathrm{KAl}_{2} \mathrm{Si}_{3} \mathrm{AlO}_{10}(\mathrm{OH})_{2}\right)$ and $\mathrm{C}$ represents calcite $\left(\mathrm{CaCO}_{3}\right)$ phases.

All unmarked peaks represent the calcite phase. The chemical composition of the waste calcite is listed in Table 1. The major impurities determined by XRF were $\mathrm{SO}_{3}(4.63$ mass \%), $\mathrm{SiO}_{2}$ (1.91 mass\%), and $\mathrm{Al}_{2} \mathrm{O}_{3}$ (0.85 mass\%).

Figure 2 shows the SEM micrographs of the reagent-grade calcite (a) and the waste calcite (b). The reagent-grade calcite had a well-defined rhombohedral crystal morphology with

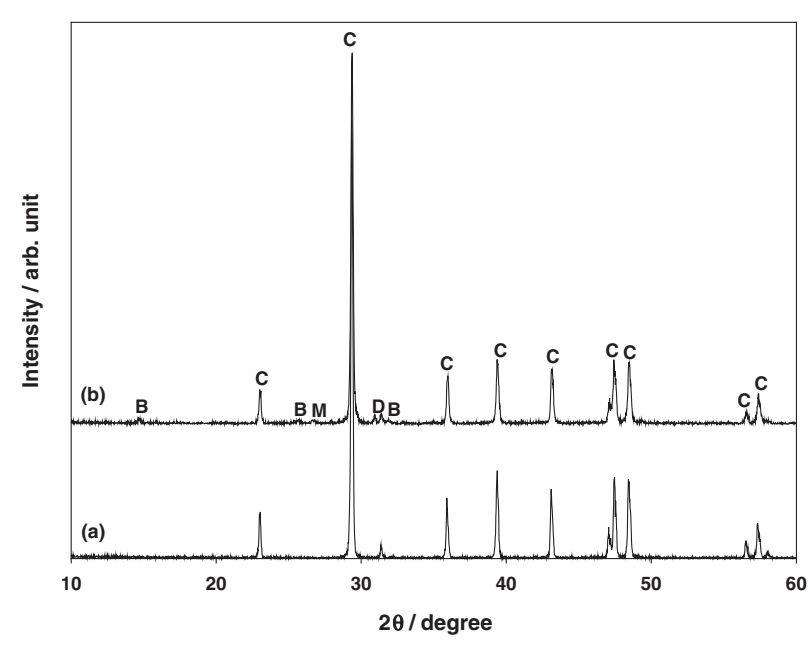

Fig. 1 X-ray diffraction patterns of reagent-grade calcite (a) and waste calcite (b). Here, B represents bassanite $\left(\mathrm{CaSO}_{4} \cdot 0.5 \mathrm{H}_{2} \mathrm{O}\right)$, D represents dolomite $\left(\mathrm{CaMg}\left(\mathrm{CO}_{3}\right)_{2}\right), \mathrm{M}$ represents muscovite $\left(\mathrm{KAl}_{2} \mathrm{Si}_{3} \mathrm{AlO}_{10}(\mathrm{OH})_{2}\right)$ and $\mathrm{C}$ represents calcite $\left(\mathrm{CaCO}_{3}\right)$ phases.

Table 1 XRF analysis of the waste calcite produced by the carbonation of flue gas desulfurization (FGD) gypsum.

\begin{tabular}{ll}
\hline Chemical composition & Value (mass\%) \\
\hline $\mathrm{CaO}$ & 51.64 \\
$\mathrm{SO}_{3}$ & 4.63 \\
$\mathrm{SiO}_{2}$ & 1.91 \\
$\mathrm{Al}_{2} \mathrm{O}_{3}$ & 0.85 \\
$\mathrm{MgO}$ & 0.57 \\
$\mathrm{Fe}_{2} \mathrm{O}_{3}$ & 0.41 \\
$\mathrm{~K}_{2} \mathrm{O}$ & 0.31 \\
$\mathrm{Na}_{2} \mathrm{O}$ & 0.04 \\
$\mathrm{TiO}_{2}$ & 0.03 \\
$\mathrm{P}_{2} \mathrm{O}_{5}$ & 0.02 \\
$\mathrm{MnO}$ & $<0.01$ \\
Ignition loss & 39.59 \\
\hline
\end{tabular}

clean surfaces. The waste calcite particles were of irregular shape having a broad size distribution. The difference in particle size was confirmed by BET measurement as well. The specific surface area of the waste-calcite and the reagentgrade calcite were $3.76 \mathrm{~m}^{2} / \mathrm{g}$ and $0.68 \mathrm{~m}^{2} / \mathrm{g}$, respectively.

$\mathrm{X}$-ray diffraction study does not provide enough information on the adsorption product since it is extremely thin. The thickness of the adsorption product is only few tenths of nanometers while X-ray penetrates through tenth of micrometers. Therefore, it is generally not possible to obtain valuable data by conventional X-ray diffraction. The reagentgrade calcite did not reveal any detectable changes before and after exposing them to the solution for $48 \mathrm{~h}$. However, in case of the waste-calcite sample, minor changes in the X-ray diffraction patterns are noticed. Figure 3(a)(b)(c) shows the $\mathrm{X}$-ray diffraction patterns of waste calcite samples after exposing them to the solution for $1 \mathrm{~h}$ (b) and $48 \mathrm{~h}$ (c) along with the as-prepared condition (a). As previously stated, the waste calcite contained bassanite $\left(\mathrm{CaSO}_{4} \cdot 0.5 \mathrm{H}_{2} \mathrm{O}\right)$, dolomite $\left(\mathrm{CaMg}\left(\mathrm{CO}_{3}\right)_{2}\right)$, and muscovite $\left(\mathrm{KAl}_{2} \mathrm{Si}_{3} \mathrm{AlO}_{10}(\mathrm{OH})_{2}\right)$ as its major impurity phases. The dolomite and muscovite peak are seen to remain after the expoure to $0.89 \mathrm{mM} \mathrm{CdCl}_{2}$ solution for $48 \mathrm{~h}$. On the contrary, the bassanite peaks vanish almost 

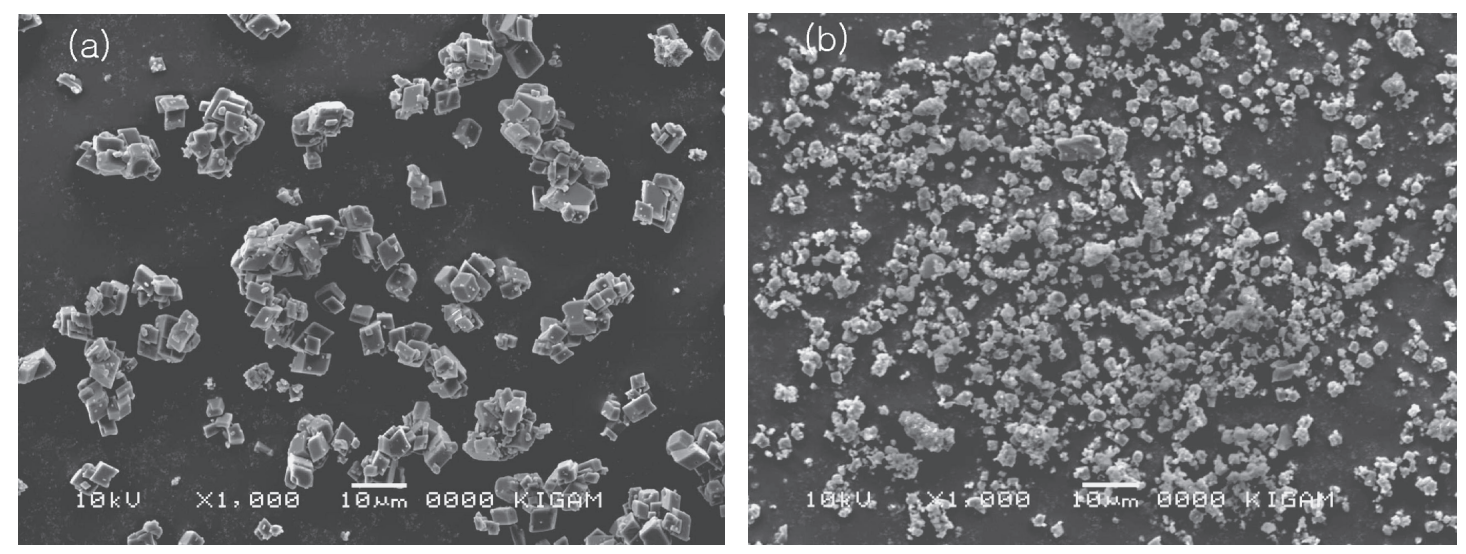

Fig. 2 FE-SEM images of calcite particles: (a) reagent-grade calcite (b) waste calcite.

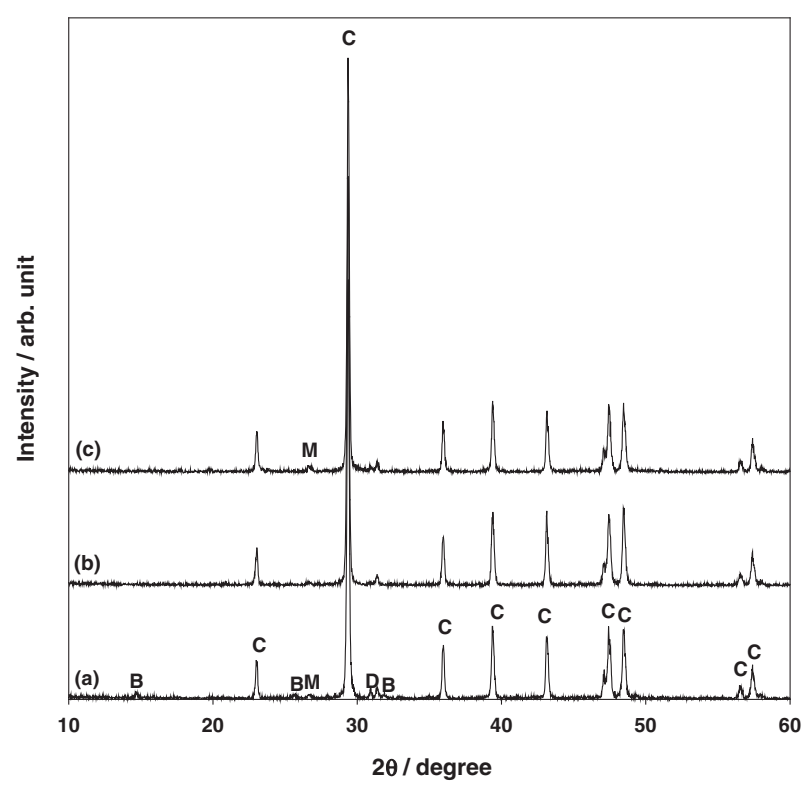

Fig. 3 X-ray diffraction patterns of waste calcite: (a) as prepared (b) after the exposure to $0.89 \mathrm{mM} \mathrm{CdCl}_{2}$ solution for $1 \mathrm{~h} \mathrm{(c)} \mathrm{after} \mathrm{the} \mathrm{exposure} \mathrm{to}$ $0.89 \mathrm{mM} \mathrm{CdCl} 2$ solution for $48 \mathrm{~h}$. Here, B represents bassanite $\left(\mathrm{CaSO}_{4}\right.$. $\left.0.5 \mathrm{H}_{2} \mathrm{O}\right)$, D represents dolomite $\left(\mathrm{CaMg}\left(\mathrm{CO}_{3}\right)_{2}\right)$, $\mathrm{M}$ represents muscovite $\left(\mathrm{KAl}_{2} \mathrm{Si}_{3} \mathrm{AlO}_{10}(\mathrm{OH})_{2}\right)$ and $\mathrm{C}$ represents calcite $\left(\mathrm{CaCO}_{3}\right)$ phases.

completely suggesting that it dissolves rapidly in $1 \mathrm{~h}$. The instant dissolution of bassanite should affect the dissolution of $\mathrm{Ca}$ (II) and adsorption of $\mathrm{Cd}$ (II) greatly since it provides extra $\mathrm{Ca}$ (II) ions to the solution in addition to those from the dissolution of calcite itself. The other two phases are seen to remain intact even after the exposure for $48 \mathrm{~h}$.

\subsection{Uptake of $\mathrm{Cd}(\mathrm{II})$}

It is important to monitor the extent of not only $\mathrm{Cd}(\mathrm{II})$ removed from the solution but also of $\mathrm{Ca}$ (II) dissolved into the solution. It was found that the sorption of $\mathrm{Cd}(\mathrm{II})$ on calcite crystals was closely related to the dissolution of $\mathrm{Ca}$ (II) from the surface. As a matter of fact, this condition was dissimilar to the previous study in that $\mathrm{CaCO}_{3}$ was stabilized for extended period of time before the addition of $\mathrm{Cd}(\mathrm{II})$ ions. ${ }^{6}$ We believe that our experiment represents the conditions more closely the practical wastewater treatment. Their amounts were measured as function of time and presented in Table 2 and Fig. 4. In Table 2, $\mathrm{C}_{0}$ and $\mathrm{C}_{48}$ are the initial
Table 2 Uptake of Cd(II) by the waste calcite and the reagent-grade calcite after the exposure to $0.89 \mathrm{mM} \mathrm{CdCl} 2$ solution for $48 \mathrm{~h}$.

\begin{tabular}{lccccc}
\hline \multicolumn{1}{c}{ Adsorbent } & $\begin{array}{c}\mathrm{C}_{0} \\
(\mathrm{mM})\end{array}$ & $\begin{array}{c}\mathrm{C}_{48} \\
(\mathrm{mM})\end{array}$ & $\begin{array}{c}\mathrm{C}_{0}-\mathrm{C}_{48} \\
(\mathrm{mM})\end{array}$ & $\begin{array}{c}\mathrm{U}_{\mathrm{Cd}} \\
(\mathrm{mmol} / \mathrm{g})\end{array}$ & $\begin{array}{c}\mathrm{U}_{\mathrm{Cd}} / \mathrm{BET} \\
\left(\mathrm{mmol} / \mathrm{m}^{2}\right)\end{array}$ \\
\hline Waste calcite & 0.89 & 0.0863 & 0.8037 & 0.0803 & 0.0214 \\
\hline Reagent-grade calcite & 0.89 & 0.8362 & 0.0538 & 0.0053 & 0.0078 \\
\hline
\end{tabular}

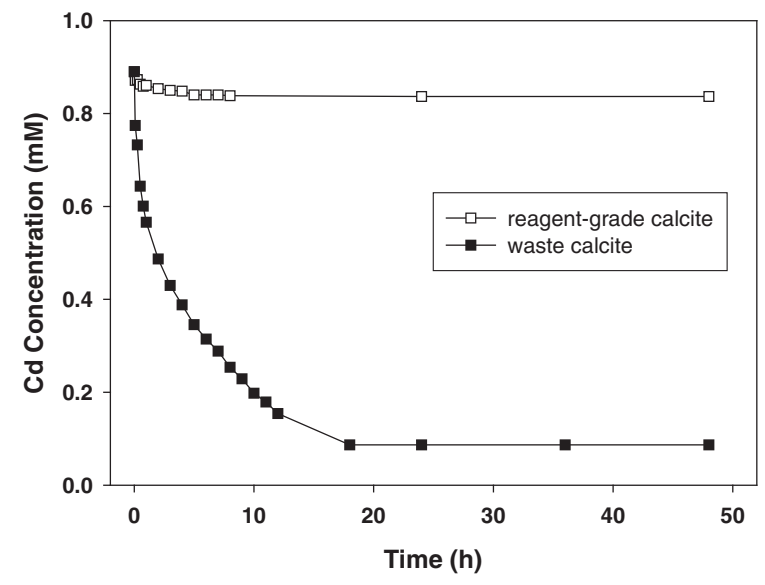

Fig. 4 Uptake of $\mathrm{Cd}(\mathrm{II})$ with time by the waste calcite and the reagentgrade calcite during the exposure to $0.89 \mathrm{mM} \mathrm{CdCl}_{2}$ solution.

Cd(II) concentration and the concentration after the exposure to the solution for $48 \mathrm{~h}$, respectively. $\mathrm{U}_{\mathrm{Cd}}$ is the amount of $\mathrm{Cd}(\mathrm{II})$ uptake per gram of calcite added and $\mathrm{U}_{\mathrm{Cd}} / \mathrm{BET}$ is the amount of $\mathrm{Cd}(\mathrm{II})$ uptake per unit surface area. $\mathrm{U}_{\mathrm{Cd}} / \mathrm{BET}$ was calculated to evaluate the effect of BET surface area on the adsorption and dissolution reactions.

As is obvious in Fig. 4, there was a rapid uptake of $\mathrm{Cd}(\mathrm{II})$ during the early hours of adsorption experiment. It then diminishes reaching a limiting value after about $18 \mathrm{~h}$. The fast initial uptake is often observed and interpreted as adsorption while the slow second uptake is explained as precipitation, recrystallization, and/or diffusion into solid for the sorption. ${ }^{1,6,17)}$ After $18 \mathrm{~h}$, further uptake of Cd(II) does not occur at least in a macroscopic scale. This may be due to the unavailability of exchangeable adsorption sites for $\mathrm{Cd}(\mathrm{II})$ ions, which prevents further adsorption of $\mathrm{Cd}(\mathrm{II})$.

The amount of $\mathrm{Cd}(\mathrm{II})$ removed by the waste calcite was significantly higher than that by the reagent-grade calcite. After the exposure for $48 \mathrm{~h}$, about $93 \%$ of initial Cd(II) was 


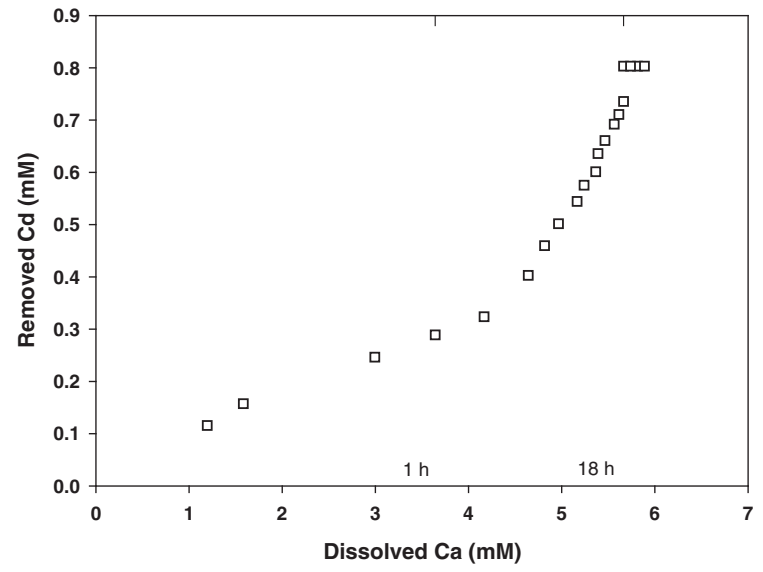

Fig. 5 The relationship between dissolved $\mathrm{Ca}$ (II) from and removed $\mathrm{Cd}$ (II) by the waste calcite in $0.89 \mathrm{mM} \mathrm{CdCl}_{2}$ solution.

removed by waste calcite (Table 2 ). On the contrary, the reagent-grade calcite removed only $6 \% \mathrm{Cd}(\mathrm{II})$. It is possible that the remarkable difference might be originated from the surface area difference. The BET surface area of waste calcite is about 5.5 times larger than that of the reagent-grade calcite. However, the BET surface-area normalized uptake $\left(\mathrm{U}_{\mathrm{Cd}} / \mathrm{BET}\right)$ suggests that $\mathrm{Cd}(\mathrm{II})$ uptake capacity of waste calcite is still 3 times higher than that of the reagent-grade calcite (Table 2).

\subsection{Dissolution of $\mathbf{C a}(\mathrm{II})$}

$\mathrm{CaCO}_{3}(\mathrm{~s})$ is thermodynamically stable but it is not a sparingly soluble solid considering the solubility product of calcite $(\log \mathrm{K}=-8.4){ }^{6)}$ In addition, it reacted in water with atmospheric $\mathrm{CO}_{2}$ gas $\left(p_{\mathrm{CO}_{2}}=10^{-3.5}\right)$ (eq. (1)). It is not clear whether the exchange reaction of $\mathrm{Cd}^{2+}$ for $\mathrm{Ca}^{2+}$ would proceed simultaneously or subsequently with $\mathrm{Ca}$ dissolution.

In view of the generally accepted mechanism that $\mathrm{Cd}(\mathrm{II})$ adsorption occurs via the ion exchange reaction of $\mathrm{Cd}(\mathrm{II})$ with $\mathrm{Ca}$ (II) on the surface of calcite (eq. (2)), it is important to monitor the $\mathrm{Ca}(\mathrm{II})$ dissolution with time. At the very beginning of the experiments the aqueous solution is virtually free of calcium, but the concentration increases as the $\mathrm{CaCO}_{3}$ solids dissolve (eq. (1)).

Figure 5 shows the relationship between dissolved $\mathrm{Ca}(\mathrm{II})$ and removed $\mathrm{Cd}(\mathrm{II})$ in $0.89 \mathrm{mM} \mathrm{CdCl} \mathrm{Cl}_{2}$ solution for waste calcite. This behavior was similar in the case of reagent-grade calcite but with much less quantity. During the 1st hour of adsorption, $\mathrm{Ca}$ (II) dissolved fast to about $3.7 \mathrm{mM}$ removing about $0.3 \mathrm{mM} \mathrm{Cd}(\mathrm{II})$. Afterwards, the dissolution of $\mathrm{Ca}$ (II) became rather tedious. After about $18 \mathrm{~h}$, both became negligible probably due to the surface coverage of calcite with less-soluble $\mathrm{CdCO}_{3}$ or $(\mathrm{Cd}, \mathrm{Ca}) \mathrm{CO}_{3}$ layer which deters further dissolution of $\mathrm{Ca}(\mathrm{II})$.

The dissolution of $\mathrm{Ca}$ (II) from the waste calcite was much higher than that from the reagent-grade calcite. Figure 6 shows the dissolution of $\mathrm{Ca}$ (II) from the waste calcite and the reagent-grade calcite with time. The initial rapid dissolution of $\mathrm{Ca}$ (II) reaches to an equilibrium after $18 \mathrm{~h}$. An easy way to explain the dissolution behavior of two calcite samples would be the surface area difference. Therefore, the effect of the surface area was examined with BET data. Table 3 summa-

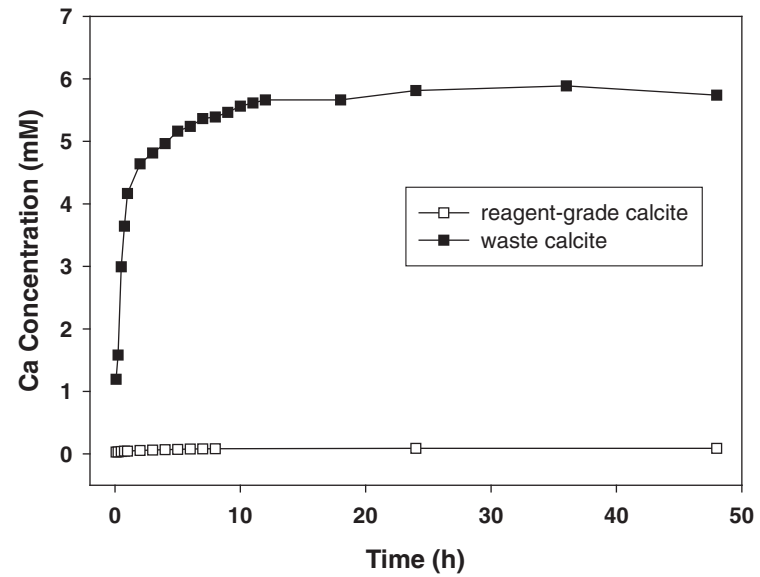

Fig. 6 Dissolution of $\mathrm{Ca}$ (II) with time from the waste calcite and the reagent-grade calcite during the exposure to $0.89 \mathrm{mM} \mathrm{CdCl}_{2}$ solution.

Table 3 Dissolution of $\mathrm{Ca}$ (II) from the waste calcite and the reagent-grade calcite during the exposure to $0.89 \mathrm{mM} \mathrm{CdCl}_{2}$ solution for $48 \mathrm{~h}$.

\begin{tabular}{lccccc}
\hline \multicolumn{1}{c}{ Adsorbent } & $\begin{array}{c}\mathrm{C}_{0} \\
(\mathrm{mM})\end{array}$ & $\begin{array}{c}\mathrm{C}_{48} \\
(\mathrm{mM})\end{array}$ & $\begin{array}{c}\mathrm{C}_{48}-\mathrm{C}_{0} \\
(\mathrm{mM})\end{array}$ & $\begin{array}{c}\mathrm{D}_{\mathrm{Ca}} \\
(\mathrm{mmol} / \mathrm{g})\end{array}$ & $\begin{array}{c}\mathrm{D}_{\mathrm{Ca}} / \mathrm{BET} \\
\left(\mathrm{mmol} / \mathrm{m}^{2}\right)\end{array}$ \\
\hline Waste calcite & 0 & 5.740 & 5.740 & 0.5739 & 0.1526 \\
\hline Reagent-grade calcite & 0 & 0.089 & 0.089 & 0.0089 & 0.0131 \\
\hline
\end{tabular}

rizes $\mathrm{Ca}(\mathrm{II})$ dissolution data. Here, $\mathrm{C}_{0}$ and $\mathrm{C}_{48}$ is the initial $\mathrm{Ca}$ (II) concentration and the concentration after $48 \mathrm{~h}$ in the solution, respectively. $\mathrm{D}_{\mathrm{Ca}}$ is the amount of $\mathrm{Ca}(\mathrm{II})$ per gram of calcite and $\mathrm{D}_{\mathrm{Ca}} / \mathrm{BET}$ is the amount of dissolved $\mathrm{Ca}$ (II) per unit area. $\mathrm{D}_{\mathrm{Ca}} / \mathrm{BET}$ was calculated to normalize the dissolution data with BET surface area. It is seen that the amount of dissolved $\mathrm{Ca}(\mathrm{II})\left(\mathrm{D}_{\mathrm{Ca}}\right)$ from the waste calcite is about 64 times higher than that by the reagent calcite. When it is normalized by the BET surface area $\left(\mathrm{D}_{\mathrm{Ca}} / \mathrm{BET}\right)$, the dissolved $\mathrm{Ca}(\mathrm{II})\left(\mathrm{D}_{\mathrm{Ca}}\right)$ from the waste calcite is still one order higher than that from the reagent-grade calcite. To summarize, the use of waste calcite instead of the reagent-grade calcite increased the $\mathrm{Cd}$ (II) uptake and $\mathrm{Ca}$ (II) dissolution by 3 fold and 12 fold, respectively. As a matter of fact, in a similar experiment, Prieto et al. ${ }^{18)}$ found that BET surface area was not a good estimate of the reactive surface reaction. Therefore, it is obvious that we should seek an answer other than the high surface area whether BET surface area criteria is appropriate or not in our system.

\subsection{Dissolution of bassanite}

The waste calcite is known to carry impurities which are retained in FGD gypsum. ${ }^{13)}$ The waste calcite used in this study contained major impurities as dolomite $\left(\mathrm{CaMg}\left(\mathrm{CO}_{3}\right)_{2}\right)$, bassanite $\left(\mathrm{CaSO}_{4} \cdot 0.5 \mathrm{H}_{2} \mathrm{O}\right)$ and muscovite $\left(\mathrm{KAl}_{2} \mathrm{Si}_{3} \mathrm{AlO}_{10^{-}}\right.$ $\left.(\mathrm{OH})_{2}\right)$. The bassanite phase is likely to be stemmed from a side reaction of the carbonation of gypsum $\left(\mathrm{CaSO}_{4} \cdot 2 \mathrm{H}_{2} \mathrm{O}\right)$, and may exist as independent particles.

The bassanite dissolves relatively fast in an aqueous solution. Amathieu and Boistelle ${ }^{19)}$ investigated the amounts of dissolving bassanite as a function of time. They reported that about $42 \mathrm{~g} / \mathrm{L}$ of bassanite was immediately dissolved. In our experiment, the amount of bassanite in the waste calcite could be estimated to be $0.463 \mathrm{~g} / \mathrm{L}\left(5.78 \times 10^{-3} \mathrm{~mol} / \mathrm{L}\right)$ 
which is far less than a possibly soluble value $\left(3.37 \times 10^{-2}\right.$ mol/L). ${ }^{19)}$ The dissolution of the bassanite could proceed according to eq. (4).

$$
\mathrm{CaSO}_{4} \cdot 0.5 \mathrm{H}_{2} \mathrm{O} \rightarrow \mathrm{Ca}^{2+}+\mathrm{SO}_{4}{ }^{2-}+0.5 \mathrm{H}_{2} \mathrm{O}
$$

The dissolution of the bassanite provides an instant supply of ions $\left(\mathrm{Ca}^{2+}, \mathrm{SO}_{4}{ }^{2-}\right)$ to calcite/solution interface which can participate in the exchange reaction of $\mathrm{Cd}(\mathrm{II})$. The maximum amount of $\mathrm{Ca}(\mathrm{II})$ to be dissolved in the waste calcite can be assumed to be $5.78 \mathrm{mM}$ based on the amount of sulfur obtained from XRF analysis. This suggests that $5.78 \mathrm{mM}$ of $\mathrm{Ca}$ (II) could be dissolved from bassanite to the solution in addition to $\mathrm{Ca}$ (II) from the inherent dissolution of $\mathrm{CaCO}_{3}$. The amount is a surprisingly high since it is comparable to the total amount of $\mathrm{Ca}$ (II) $(5.74 \mathrm{mM})$ measured after $48 \mathrm{~h}\left(\mathrm{C}_{48}-\right.$ $\mathrm{C}_{0}$ in Table 3 ). If the calculation is correct, then this suggests that most of $\mathrm{Ca}$ (II) ions in the solution could be originated from the bassanite. Realizing that significant amount of $\mathrm{Ca}$ (II) and sulfate ions are supplied to the solution, the enhancement of Cd(II) uptake should be explained accordingly.

In this respect, the work of Prieto et al. ${ }^{18)}$ is interesting where two aragonite grains and a calcite fragment were used to study the uptake of $\mathrm{Cd}$. There was no second phase dissolution in their system and their aragonite samples contain only $0.5-0.7$ mass $\%$ impurities other than the calcite. However, they observed that $\mathrm{Cd}$ (II) uptake by calcite was lower than that by two aragonites. They attributed the inhibition of $\mathrm{Cd}$ (II) sorption on calcite to quicker coverage of the calcite surface by thin epitaxial crystallites which prevent further dissolution of $\mathrm{Ca}(\mathrm{II})$ and thus $\mathrm{Cd}(\mathrm{II})$ uptake. Even though the same mechanism may work in our system to enhance the uptake of $\mathrm{Cd}(\mathrm{II})$, we believe that the fast $\mathrm{Ca}(\mathrm{II})$ dissolution from bassanite phase has a more decisive effect.

The effect of sulfate on $\mathrm{Cd}(\mathrm{II})$ sorption appears to be inconclusive. Akin and Lagerwerff ${ }^{20}$ ) showed that $\mathrm{CaCO}_{3}$ solubility increased in the presence of sulfate in the solution. Meanwhile, Weijden et al. ${ }^{21)}$ reported that the sulfate ion suppress the fast initial adsorption of $\mathrm{Cd}(\mathrm{II})$ on calcite. We do not have any ground to evaluate the effect of sulfate further since we did not intend and even realize the instant supply of sulfate ion to the solution to begin with.

Obviously, the understanding of the exact mechanism in the enhancement of $\mathrm{Cd}(\mathrm{II})$ uptake by waste calcite needs a lot more elaboration and careful study. Nevertheless, it is evident that the enhancement is closely related to the instant dissolution of bassanite which supplies significant amounts of $\mathrm{Ca}$ (II) and sulfate ions to the solution changing the chemistry at calcite/solution interface.

\section{Conclusions}

The uptake of $\mathrm{Cd}(\mathrm{II})$ by waste calcite in $0.89 \mathrm{mM} \mathrm{Cd}(\mathrm{II})$ solution was investigated in a batch experiment. The waste calcite particles were obtained from the carbonation of FGD gypsum and a reagent grade of calcite was used for a comparative study. The results are as follows:

(1) The waste calcite contained bassanite, dolomite and muscovite as its major impurity phases. The bassanite phase dissolved almost completely during the exposure for $1 \mathrm{~h}$ to $0.89 \mathrm{mM} \mathrm{Cd}(\mathrm{II})$ solution while dolomite, and muscovite phases remained intact for $48 \mathrm{~h}$. The instant dissolution of bassanite provided significant amounts of $\mathrm{Ca}$ (II) and sulfate ions to the solution resulting in the enhancement of $\mathrm{Cd}(\mathrm{II})$ uptake. The maximum amount of $\mathrm{Ca}$ (II) to be dissolved from the bassanite phase was assumed to be $5.78 \mathrm{mM}$ based on the amount of sulfur content obtained from XRF analysis.

(2) The Waste calcite removed about $90 \%$ of initial Cd(II) while the reagent-grade calcite removed only $6 \%$ after the exposure for 2 days to $0.89 \mathrm{mM} \mathrm{Cd}(\mathrm{II})$ solution. The uptake of $\mathrm{Cd}$ (II) by the waste calcite was significantly higher than that by the reagent-grade calcite even after normalizing the BET surface area.

(3) The uptake of $\mathrm{Cd}(\mathrm{II})$ was proportionally related to $\mathrm{Ca}(\mathrm{II})$ dissolution. Cadmium was removed fast during the early stage of reaction reaching an equilibrium after about $18 \mathrm{~h}$ due probably to the surface coverage by $\mathrm{CdCO}_{3}$ layer.

\section{Acknowledgements}

This research was supported by the Basic Research Project of the Korea Institute of Geoscience and Mineral Resources (KIGAM) funded by the Ministry of Knowledge Economy of Korea.

\section{REFERENCES}

1) J. M. Zachara, C. E. Cowan and C. T. Resch: Geochim. Cosmochim. Acta 55 (1991) 1549-1562.

2) A. García-Sánchez and E. Álvarez-Ayuso: Miner. Eng. 15 (2002) 539_ 547.

3) Ö. Yavuz, R. Guzel, F. Aydin, I. Tegin and R. Ziyadanogullari: Pol. J. Environ. Stud. 16 (2007) 467-471.

4) M. B. McBride: Soil Sci. Soc. Am. J. 44 (1980) 26-28.

5) S. L. Stipp, M. F. Hochella Jr, G. A. Parks and J. O. Leckie: Geochim. Cosmochim. Acta 56 (1992) 1941-1954.

6) J. A. Davis, C. C. Fuller and A. D. Cook: Geochim. Cosmochim. Acta 51 (1987) 1477-1490.

7) V. G. R. Chada, D. B. Hausner, D. R. Strongin, A. A. Rouff and R. J. Reeder: J. Colloid Interface Sci. 288 (2005) 350-360.

8) M. Shirvani, H. Shariatmadari, M. Kalbasi, F. Nourbakhsh and B. Najafi: Colloids Surf. A 287 (2006) 182-190.

9) A. Martin-Garin, P. Van Cappellen and L. Charlet: Geochim. Cosmochim. Acta 67 (2003) 2763-2774.

10) C. C. Fuller and J. A. Davis: Geochim. Cosmochim. Acta 51 (1987) 1491-1502.

11) S. K. Thakur, N. K. Tomar and S. B. Pandeya: Geoderma 130 (2006) 240-249.

12) M.-I. M. Chou, J. A. Bruinius, V. Benig, S.-F. J. Chou and R. H. Carty: Energy Sources Part A 27 (2005) 1061-1071.

13) W. C. Burnett, M. K. Schultz and C. D. Hull: J. Environ. Radioact. 32 (1996) 33-51.

14) K. Song, W. Kim, T. Ryu, K.-W. Ryu, J.-H. Bang and J.-N. Jang: Mater. Trans. 52 (2011) 224-228.

15) Y. Wang, X. Tang, Y. Chen, L. Zhan, Z. Li and Q. Tang: J. Hazard. Mater. 172 (2009) 30-37.

16) Z. A. Al-Anber and M. A. D. Matouq: J. Hazard. Mater. 151 (2008) 194-201.

17) C. C. Fuller and J. A. Davis: Geochim. Cosmochim. Acta 51 (1987) 1491-1502.

18) M. Prieto, P. Cubillas and Á. Fernández-Gonzalez: Geochim. Cosmochim. Acta 67 (2003) 3859-3869.

19) L. Amathieu and R. Boistelle: J. Cryst. Growth 88 (1988) 183-192.

20) G. W. Akin and J. V. Lagerwerff: Geochim. Cosmochim. Acta 29 (1965) 353-360.

21) R. D. van der Weijden, J. Meima and R. N. J. Comans: Mar. Chem. 57 (1997) 119-132. 